\title{
Homenagem à Dra. Ana Maria L. Tepedino
}

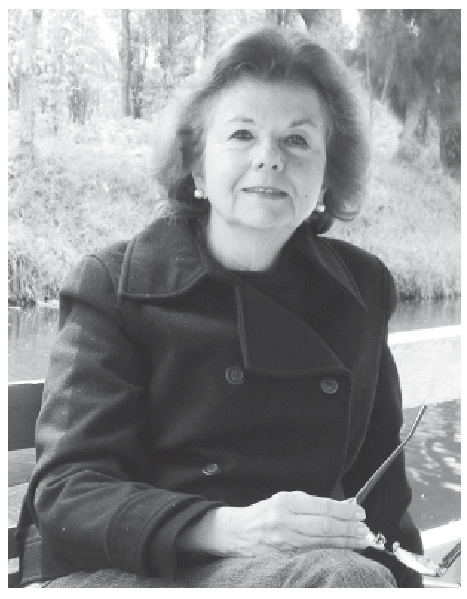

conferências, orientações de trabalhos, grupos de pesquisa, enfim produção acadêmica, mas também pela capacidade de gestão quando foi Coordenadora de Graduação, de Pós-graduação e da Teologia a Distância.

Ela tinha a capacidade de ser estrela com muita competência - e beleza - mas sempre tendo a seu lado uma equipe que preparasse e atuasse comunitariamente no desempenho dos eventos e dos trabalhos acadêmicos. Ressaltava que esse jeito comunitário de ser é típico da mulher. Tinha a capacidade de juntar e organizar grupos e equipes sempre que se tratasse de resolver algum problema ou de promover iniciativas a serviço da Academia e da Igreja. Detalhe: sempre chamava alunas e alunos para conversar, envolvendo-os na própria elaboração das suas iniciativas.

Preparava com esmero liturgias ligadas à vida da Universidade, seja para comemorar alguma data significativa, como as formaturas, seja para 
iniciar o ano letivo ou encerrar uma Semana Teológica. Nos inúmeros encontros de mulheres que organizou ou dos quais participou, no Brasil e no exterior, manteve ao mesmo tempo seu ar de nobreza e sua proximidade amiga, solidária.

Deixa-nos - na teoria e na prática - a tão desejada "Eclesiologia de Comunhão" que não discrimina ninguém.

Sua fé era contagiosa e hoje arrasta com ela uma multidão de alunas e alunos, colegas, amigos e até mestres, como ficou evidenciado na sua missa de sétimo dia.

Parabéns, Ana Maria!

Do regaço materno do Espírito, onde você vive hoje, envia-nos Amor e Luz!

Rio de Janeiro, 20 de setembro de 2018

Dra. Tereza Maria Pompéia Cavalcanti Docente do Departamento de Teologia da Pontifícia Universidade Católica do Rio de Janeiro E-mail: terezapc@puc-rio.br 